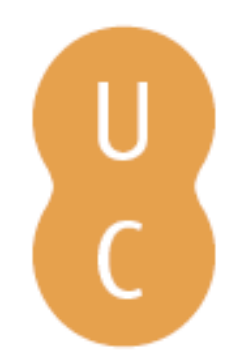

\title{
nommalina
}

\section{Gymnast wrist: the ulnar variance phenomenon}
Autor(es):
Claessens, Albrecht L
Publicado por: Imprensa da Universidade de Coimbra
URL persistente:
URI:http://hdl.handle.net/10316.2/31702
DOI:
DOI:http://dx.doi.org/10.14195/978-989-26-0506-7_6

Accessed : $\quad$ 26-Apr-2023 12:27:21

A navegação consulta e descarregamento dos títulos inseridos nas Bibliotecas Digitais UC Digitalis, UC Pombalina e UC Impactum, pressupõem a aceitação plena e sem reservas dos Termos e Condições de Uso destas Bibliotecas Digitais, disponíveis em https://digitalis.uc.pt/pt-pt/termos.

Conforme exposto nos referidos Termos e Condições de Uso, o descarregamento de títulos de acesso restrito requer uma licença válida de autorização devendo o utilizador aceder ao(s) documento(s) a partir de um endereço de IP da instituição detentora da supramencionada licença.

Ao utilizador é apenas permitido o descarregamento para uso pessoal, pelo que o emprego do(s) título(s) descarregado(s) para outro fim, designadamente comercial, carece de autorização do respetivo autor ou editor da obra.

Na medida em que todas as obras da UC Digitalis se encontram protegidas pelo Código do Direito de Autor e Direitos Conexos e demais legislação aplicável, toda a cópia, parcial ou total, deste documento, nos casos em que é legalmente admitida, deverá conter ou fazer-se acompanhar por este aviso.

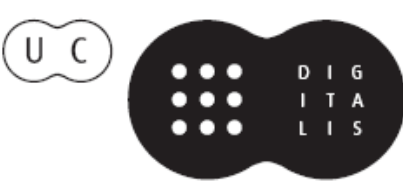


Manuel J. Coelho e Silva António J. Figueiredo Marije T. Elferink-Gemser Robert M. Malina Editors
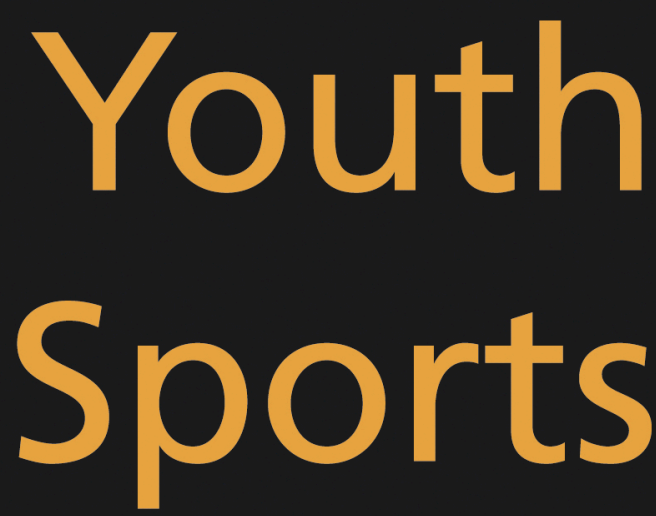

\section{Growth, Maturation and Talent}




\title{
EDIC̣̃̃o
}

Imprensa da Universidade de Coimbra

Email: imprensauc@ci.uc.pt

URL: http://www.uc.pt/imprensa_uc

Vendas online: http://www.livrariadaimprensa.com

\section{CONCEPÇÃO GRÁFICA}

António Barros

\section{EXECUÇÃO GRÁFICA}

\author{
Norprint
}

ISBN

978-989-26-0005-5

\section{DEPÓSITO LEGAL}


Manuel J. Coelho e Silva António J. Figueiredo Marije T. Elferink-Gemser

Robert M. Malina

Editors
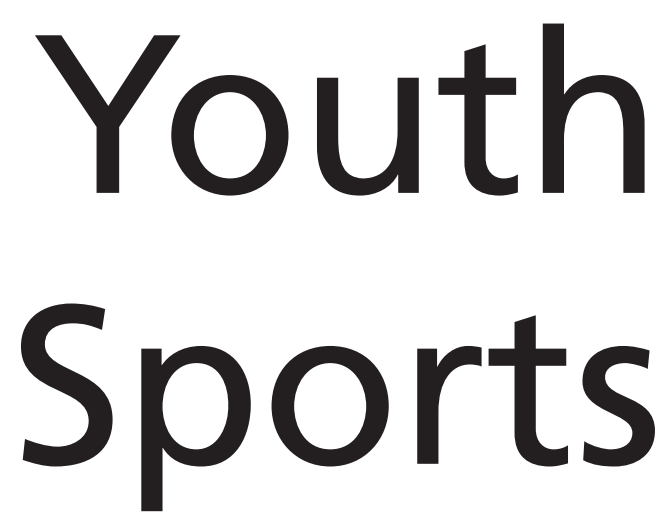

Growth, Maturation and Talent

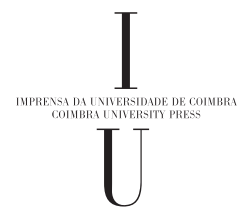


Part I:

GROWTH AND MATURATION 


\section{CHAPTER 6: GYMNAST WRIST: the ulnar variance phenomenon *}

Albrecht L Claessens

\section{INTRODUCTION}

Nowadays, elite sports for children and youth becomes more and more a public phenomenon. The extreme training demands and controlling young athletes by coaches, often with approval of the parents, together with changes in expectations of performance at top levels, has resulted in public and medical concerns. (Bar-Or, 1996; Ryan, 1995) This is especially true in sports as gymnastics, in which a prepubertal physique is a prerequisite for top level gymnastic achievements. (Claessens, 1999) Further, the demands of artistic gymnastics for females have also changed, eg requirements for more difficult routines, year-round training, enhanced mental stress, and so on (Gould, 200 I; Jemni et al., 200 I; Normile, 1996; Ryan, 1995).

The significant growth and popularity of women's gymnastics became more and more evident after the 1972 and 1976 Olympics, where stars as Olga Korbut and Nadia Comaneci introduced the world, via the media, to this artistic sport (Ryan, 1995). Accompanying this popularity has been the increasingly dominant performance of younger, smaller-sized gymnasts (Caine et al., 1996; Claessens, 1999). Average ages, and heights and weights of female gymnasts participating at Olympic and World competitions have declined over the past 20 to 30 years (Claessens, 1999). Over a period of about 25 years, the average chronological age of elite female gymnasts declined by 6 years. Secular declines in mean heights and weights parallel the decrease in chronological age. Over the same period, mean height have declined by 4 to 5 $\mathrm{cm}$. The secular decline in height is accompanied by a dramatic reduction in mean weight of about 8 to $9 \mathrm{~kg}$ (Claessens, 1999; Claessens et al., 1991). Comparable declines in age, height and weight were also observed in artistic female gymnasts from the United States competing at the 1992 Olympics which were $6 \%$ younger, 10\% shorter, and 22\% lighter compared to their 1976 counterparts (Ryan, 1995). The majority of elite gymnasts also tend to be later-maturing individuals (Claessens, 1999; Malina, 1999, 200 I). In general, present-day elite gymnastics has evolved to favor the body of a child in

* Based on a presentation at the Symposium Science in Artistic Gymnastics, held in Ghent, Belgium, October 27, 200I. (Claessens, 200 I) 
contrast to that of a maturing adolescent or young adult (Claessens, 1999). These observations can be in large part be attributed to 'selection' based on the direct biomechanical advantages of a prepubertal physique that include increased strength/weight ratio, greater stability, and decreased moments of inertia. Also, in sports in which performance is subjectively scored, as in gymnastics, physical characteristics in addition to skill, may have added significantly for success (Claessens, 1999; Ryan, 1995).

Not surprisingly, whereas the average age and size of competitive gymnasts have decreased, the difficulty of maneuvres practiced and performed has increased. Frequency, duration, and intensity of training also have increased. Elite-level gymnasts, for example, are reported to train around 40 h/week, 5-6 days/week, the whole year around. On avarage, these gymnasts may exercise 700 to 1300 elements per day, which correspond to 220000 to 400000 elements per year (Caine et al., 1997). These extremely high training demands and changes in expectations of the sport at elite levels (Normile, 1996) has resulted in both public and medical concerns, especially from an auxological point of view (Claessens, 1999; Malina, 200 I). It may be postulated that these very young and immature growing athletes are repeatly subject to numerous microtrauma in general, and more specifically, to chronic, long-term accumulative 'overuse' injuries, caused by strenuous, repetitive loads. Epidemiologic research of injury patterns in male and female gymnasts has been studied extensively by several authors, and reviewed by Caine and coworkers (1996).

Unlike most other sports, gymnastics requires use of the upper extremities as weight-bearing limbs, causing high-impact loads to be distributed through the elbows and wrists (Koh et al., 1992; Markolf et al., 1990). It is not unexpected that injury occurs in these regions (Caine et al., 1996). Among others, wrist pain is often viewed in gymnasts as a result of epiphysial trauma and related changes caused by repetitive gymnastic loading mainly of the distal end of the radius as its interface with the carpals, as claimed by some authors (reviewed by Caine et al., 1997). Further on, some authors claim that repetitive injury to the radial epiphysis may inhibit normal growth of the radius resulting in a 'positive ulnar variance' (Caine et al., 1996, 1997).

The aim of this study is to review the available research concerning the ulnar variance phenomenon as it is connected to the female gymnast.

\section{ULNAR-VARIANCE}

Ulnar variance refers to the relative positioning of the distal end of the ulna relative to the distal end of the radius. If the distal end of the ulna is more distally located as compared to the distal end of the radius, then the term 
positive ulnar variance (or ulnar overgrowth) is used. When the opposite is seen, i.e. the distal end of the ulna is more proximal located as compared to the distal end of the radius, the phenomenon is called negative ulnar variance (Hafner et al., 1989). Ulnar variance is mostly determined on postero-anterior radiographs of the hand and wrist, whereby several measuring methods are at hand. Different techniques has to be used for mature and immature wrists (Hafner et al., 1989; Kristensen et al., 1986; Palmer et al., 1982: Steyers and Blair, 1989).

\section{FINDINGS FROM CASE REPORTS AND CROSS-SECTIONAL STUDIES}

In general, it has been proposed by several authors that the repetive stress experienced by the skeletally immature wrist during gymnastics training (especially in the young female elite gymnast) may lead to the development of wrist pain, partial arrest of the distal radial growth plate, and the subsequent development of positive ulnar variance. This proposal suggests thus a doseresponse relationship, i.e. the closure of the radial growth plate, caused by the gymnastic training load, results in a positive ulnar variance. This line of reasoning is largely based on 'patients' or 'case'-reports, i.e. those individuals who present themselves to a clinic with wrist pain, and on cross-sectional srudies in which a relatively small number of both non-elite and elite gymnasts were studied (Albanese et al., 1989; Aldridge, 1987; Carter and Aldridge, 1988; Chang et al., 1995; Difiori et al.,1997; Mandelbaum et al., 1989). Although, on average, a positive ulnar variance in most studies could be observed, results were contradictory and controversial conclusions were made. Also, because of the small sample sizes and the selective recruitment, the subjects under study were not necessary representative of the elite gymnastic population. To our knowledge, up till now, only one study is carried out in which a representative sample of outstanding female gymnasts was undertaken (Claessens et al., 1996; De Smet et al., 1994). Ulnar variance was obtained in 20l female gymnasts, all participants at the 24th World Championships Artistic Gymnastics, held at Rotterdam, The Netherlands, October 1987 (Claessens et al., 1991). The gymnasts under study came from 27 (from in total $3 \mathrm{I}$ ) countries. Based on the final results for total team scores, the four teams that declined ranked $2^{\text {nd }}, 13^{\text {th }}, 15^{\text {th }}$, and $19^{\text {th }}$. It can thus be said that the gymnasts under study were a representative sample of the elite female gymnastic population as demonstrated by the number of subjects studied $(n=201$ ), high level of training (on average 27 hours per week, varying from 13 to 48 hours per week), competition level (world championships), and representativess of nationalities. A negative mean value for ulnar variance (Mean $=-1.4 \pm 2.6 \mathrm{~mm}$ ) was obtained, demonstrating thus a negative ulnar variance in this high elite female gymnasts. Further on, it was demonstrated that no relationship between ulnar variance on the one hand, and training and 
competition level on the other hand could be observed. Based on these results, authors could not support the dose-response relationship. These results were in accordance with the data of DiFiori et al. (1997) in non elite female gymnasts.

\section{RESULTS FROM LONGITUDINAL STUDIES}

It is demonstrated that results from different studies give controversial conclusions. This is not directly surprising, because the design of these investigations, i.e. cross-sectionnally, does not allow to draw a real cause and effect relationship. Thus, well-controlled longitudinal studies, in which elite gymnasts were followed for several years, were needed, in which the doseresponse relationship between gymnastic training and the ulnar variance phenomenon can be studied in a more effective way.

In a longitudinal study, 36 female gymnasts were annually followed for four or five occasions, with a total of 158 observations (Claessens et al., 1997). At the first observation, the age of the girls varied between 6 and 14 year. According to their training level (based on the total hours of gymnastic training per week) the total group could be divided in three subgroups: (I) a 'toplevel' group ( $n=13$, with 15 hours training / week); (2) a 'subtop' group $(n=13$, with about 5 to 7 hours training / week), and (3) a 'recreational' group ( $n=10$, with about I to 2 hours training / week). Besides stature and weight, ulnar variance was determined according to the method of Hafner et al. (1989) for immature wrists. Results for ulnar variance demonstrated that for all age categories a negative value was observed, which means that the distal end of the radius exceeds the distal end of the ulna. With increasing age, this negative ulnar variance became more pronounced, the mean varying from $-3.4 \mathrm{~mm}$ to $-6.5 \mathrm{~mm}$. These results were rather uncommon and this from two viewpoints. Firstly, compared to reference girls (Hafner et al., 1989), where a relatively stable negative ulnar variance pattern can be observed throughout the growth period, varying between $-2.5 \mathrm{~mm}$ at the age of 6 year and $-2.8 \mathrm{~mm}$ at the age of 15 year; whereas in the gymnasts' sample, an increase in negative ulnar variance could be obeserved throughout the period studied. Secondly, based on the available literature, a rather 'positive ulnar variance' was expected. However, this was not the case in this longitudinal study, indicating that, in the sample studied, gymnastic training seems not to have a negative impact on the ulnar variance phenomenon. This observation was analyzed more in detail in that way, that two extreme groups with different training loads, were also compared. Results from these analyses revealed that no statistical differences in ulnar variance between the 'top-level' and the 'recreational' groups could be observed. Based on the results and within the limitations of their study, Claessens and co-workers (1997) came to the conclusion that the ulnar variance pattern is not directly caused by the gymnastic training load, and 
could not support the dose-response relationship. It is, however, clear that more longitudinal and intervention studies are needed before more exclusive interpretations can be made.

\section{FACTORS RELATED TO THE ULNAR VARIANCE PHENOMENON}

\section{a) Methodological concerns}

Different methods are at hand to measure ulnar variance in both mature and immature wrists (Hafner et al., 1989; Kristensen et al., 1986; Palmer et al., 1982). As a result discrepancies between results were obtained using different techniques and data from different studies are not directly comparable (Steyers and Blair, 1989).

In most studies ulnar variance is determined on unilateral radiographs arbitrarily chosen. However, some authors (Claessens et al., 1998; DiFiori et al., 1997; Freedman et al., 1998) have focussed on the problem of right versus left symmetry of ulnar variance. The results of these studies, however, are not unequivocal. DiFiori et al. (1997) and Freedman et al. (1998) have demonstrated that an individual's ulnar variance is not uniformly symmetrical with the consequence that results who were obtained from different wrists are not directly comparable. In contrast, in a study on 8 - 14 year old female gymnasts, Claessens et al. (1998) did not find a significant difference between ulnar variance taken from right and left radiographs. Also, differences in ulnar variance could not be observed between the dominant and non-dominant wrists, as determined by the rotational direction a wheel is turned.

\section{b) Wrist pain and ulnar variance}

Several authors claim that wrist pain in gymnasts is associated with a positive ulnar variance (Caine et al., 1996). However, based on data gathered on 27 girls and 17 boys, who could be classified as non-elite gymnasts, training on average 11.9 hours per week, DiFiori et al. (1997) did not find a significant association between ulnar variance and wrist pain. There was also no significant association between positive radiographic findings and ulnar variance.

\section{c) Maturity status and ulnar variance}

It is often argued that the less mature the gymnast, the more negative the impact of gymnastic training on the radial growth plate, and as a consequence, a more positive ulnar variance is observed. However, based on data gathered 
on 156 world-top immature female gymnasts, no significant relationship was found between skeletal age and ulnar variance, $r=+0.16$ (Claessens et al., 1996). When the data were analysed more in detail, it was clearly demonstrated that ulnar overgrowth was not associated with advanced maturity status of the radius or earlier epiphyseo-diaphyseal fusion; rather, ulnar overgrowth was apparently associated with more advanced maturity status of the ulna (Beunen et al., 1999).

\section{d) Gymnastic training load and ulnar variance}

In most studies, especially case-reports, a dose-response relationship between training and ulnar variance is suggested. Thus, the higher the gymnasts' training and/or competition level, the more pronounced positive ulnar variance. This cause-effect relationship, however, is not equivocal concluded by all authors and need further consideration. In a study on a representative sample of outstanding (participants world championships) female gymnasts, Claessens et al. (1996) did not find any significant correlation between training status and competition scores on the one hand, and ulnar variance on the other hand, correlation values varying from $r=-0.11$ ( $r$ between starting age and ulnar variance) and $r=+0.15$ ( $r$ between competition score uneven bars and ulnar variance). Also, Difiori et al. (1997) did not find a significant association between ulnar variance and training history in 44 non-elite male and female gymnasts, aged 5.8 - 15.8 years. Also, based on data gathered on 36 female gymnasts who were followed longitudinally for four years, Claessens et al. (1997) could not demonstrate a significant influence of gymnastics training load and the ulnar variance phenomenon.

\section{e) Body build and ulnar variance}

It can be hypothesized that an 'overweight' or 'overfat' body, or a physique not fully suited for gymnastics, will be more at risk for overload or overuse injuries than a physique that is appropriate for the sport. It can thus be argued that the 'heavier' the gymnast, the higher the mechanical load on the gymnasts' wrists, resulting in a more pronounced positive ulnar variance. With the exception of some studies (Claessens et al, 1996; Boogaerts, 2002), most of the available studies of ulnar variance in gymnasts has taken the bodily characteristics of the subjects and/or patients into account. It is, however, clearly demonstrated, that female gymnasts competing at the elite level with a body physique characterized as relatively tall and a high lean body mass, not fat, are at greater risk in developing a positive ulnar variance. 


\section{f) Basic motor abilities and ulnar variance}

To our knowledge, little is known if there is any relationship between the basic motor capacity or physical fitness condition of the gymnast and ulnar variance. However, it can be argued that the relative positioning of the ulna to the radius can be influenced by some motor abilities, in general, or especially at the wrist region (e.g. strength and flexibility characteristics of the wrist, fingers, and so on). Up till now, in none of the published material concerning ulnar variance this relationship was investigated. Very recently, this relationship was studied in a group $(n=16)$ of 16-year old $(S D=2.0)$ sub-top female gymnasts. (Vandenbussche, 2002) Significant correlations between ulnar variance and some motor capacities were found: with hyper extension of the fingers $(r=+$ $0.65)$; and with hyper extension of the elbow $(r=+0.52)$. The results of this preliminary study suggest that more flexible gymnasts are at greater risk in developing a positive ulnar variance.

\section{CONCLUSIONS}

Based on the available literature of the ulnar variance in female gymnasts it can be concluded that, compared to the reference values, the observed positive ulnar variance in gymnasts is less 'dramatic' than originally stated. We support Rowlands' comment in his 'Editor's Notes' that 'The available information is scant, and much more research is needed, but so far most of these seem to be largely false alarms ... The psyche of the highly trained athlete, on the other hand, may be more susceptible to injury than the epiphysis" (Rowland, 1993, p. 300). However, the observed data from the literature poses at least the possibility that growth can be affected and the condition must certainty be taken seriously. More research is needed, especially well designed longitudinal studies taking into account a broad spectrum of factors which are connected to the ulnar variance phenomenon. Finally, the importance of optimal training programs, supervised by well-educated coaches, together with the guidance of the young gymnast by a highly qualified medical team, cannot be stressed enough.

\section{REFERENCES}

Albanese SA, Palmer AK, Kerr DR, Carpenter CW, Lisi D, Levinsohn EM (1989) Wrist pain and distal growth plate closure of the radius in gymnasts. Journal of Pediatric Orthopaedics, 9: 23-28.

Aldridge MJ (1987) Overuse injuries of the distal radial growth epiphysis. In TB Hoshizaki, JH Salmela, B Petiot (Eds). Diagnostics, treatment and analysis of gymnastic talent. Montréal: Sport Psyche Editions. Pp 25-30.

Bar-Or O (1996) The child and adolescent athlete. Oxford: Blackwell Scientific Publications. 
Beunen G, Malina RM, Claessens AL, Lefevre J, Thomis M (1999) Ulnar variance and skeletal maturity of radius and ulna in female gymnasts. Medicine and Science in Sports and Exercise, 31: 653 - 657.

Boogaerts I (2002) Relationship between ulnar variance and morphological characteristics in female gymnasts. A longitudinal study. (Unpublished master thesis / Prom. Prof. A.L. Claessens) Leuven: Faculty of Physical Education and Physiotherapy, Katholieke Universiteit Leuven.

Caine DJ, Lindner KJ, Mandelbaum BR, Sands WA (1996) Gymnastics. In DJ Caine, CG Caine, KJ Lindner (Eds). Epidemiology of Sports Injuries. Champaign, III.: Human Kinetics Publishers. Pp $213-246$.

Caine DJ, Howe W, Ross W, Bergman G (1997) Does repetitive physical loading inhibit radial growth in female gymnasts? Clinical Journal of Sport Medicine. 7: $302-$ 308.

Carter SR, Aldridge MJ (1988) Stress injury of the distal radial growth plate. Journal of Bone Joint Surgery (Br.), 70-B: 834-836.

Claessens AL (1999) Elite female gymnasts: a kinanthropometric overview. In FE Johnston, B Zemel, PB Eveleth (Eds). Human growth in context. London: SmithGordon. Pp: 273- 280.

Claessens AL (200I) Ulnar variance in female gymnasts: an overview. In M Lenoir, R Philippaerts (Eds). Science in Artistic Gymnastics. Gent (Belgium): Publicatiefonds voor Lichamelijke Opvoeding. Pp: 61-73.

Claessens AL, Veer FM, Stijnen V, Lefevre J, Maes H, Steens G, Beunen G (199|) Anthropometric characteristics of outstanding male and female gymnasts. Journal of Sports Sciences. 9: 53 - 74.

Claessens AL, Lefevre J, Beunen G, De Smet L, Veer AM (1996) Physique as a risk factor for ulnar variance in elite female gymnasts. Medicine and Science in Sports and Exercise. 28: 560 - 569.

Claessens AL, Lefevre J, Philippaerts R, Thomis M, Beunen G (1997) The ulnar variance phenomenon: a study in young female gymnasts. In N Armstrong, B Kirby, J Welsman (Eds) Children and Exercise XIX. Promoting Health and Well-Being. London: E \& FN Spon, pp 537 - 54l.

Claessens AL, Moreau M, Hochstenbach L (1998) Rotational direction and the ulnar variance phenomenon in young female gymnasts. Journal of Sports Sciences, 16: 431 $-432$.

Chang C-Y, Shih C, Penn I-W, Tiu C-M, Chang T, Wu J-J (1995) Wrist injuries in adolescent gymnasts of a Chinese Opera School: radiographic survey. Radiology, 195: 861-864.

De Smet L, Claessens A, Lefevre J, Beunen G (1994) Gymnast wrist: an epidemiologic survey of ulnar variance and stress changes of the radial physis in elite female gymnasts. The American Journal of Sports Medicine, 22: 846 - 850.

DiFiori JP, Puffer JC, Mandelbaum BR, Dorey F (1997) Distal radial growth plate injury and positive ulnar variance in nonelite gymnasts. The American Journal of Sports Medicine, 25: 763- 768.

Freedman DM, Edwards GS, Willems MJ, Meals RA (1998) Right versus left symmetry of ulnar variance. Clinical Orthopaedics and Related Research, 354: 153 - 158.

Gould D (200I) The psychology of performance excellence: the case of elite gymnastics. In M Lenoir, R Philippaerts (eds.) Science in Artistic Gymnastics. Gent (Belgium): Publicatiefonds voor Lichamelijke Opvoeding, pp 39-60. 
Hafner R, Poznanski AK, Donovan JM (1989) Ulnar variance in children: standard measurements for evaluation of ulnar shortening in juvenile rheumatoid arthritis, hereditary multiple exostosis and other bone or joint disorders in childhood. Skeletal Radiology, I 8: 513-516.

Jemni M, Friemel F, Sands W, Mikesky A (200I) Evolution du profil physiologique des gymnastes durant les 40 dernieres annees. Canadian Journal of Applied Physiology, 26: 442-456.

Koh TJ, Grabiner MD, Weiker GG (1992) Technique and ground reaction forces in the back handspring. The American Journal of Sports Medicine, 20: 61-66.

Kristensen SS, Thomassen E, Christensen F (1986) Ulnar variance determination. Journal of Hand Surgery (Br.), I I: 255 - 257.

Malina RM (1999) Growth and maturation of elite female gymnasts: is training a factor? In FE Johnston, B Zemel, PB Eveleth (Eds). Human growth in context. London: Smith-Gordon, pp 29I- 301.

Malina RM (200I) Growth and maturity of young artistic gymnasts: status, progress, and issues. In M Lenoir, R Philippaerts (Eds). Science in Artistic Gymnastics. Gent (Belgium): Publicatiefonds voor Lichamelijke Opvoeding, pp 21-38.

Mandelbaum BR, Bartolozzi AR, Davis CA, Teurlings L, Bragonier B (1989) Wrist pain syndrome in the gymnast: pathogenetic, diagnostic, and therapeutic considerations. American Journal of Sports Medicine, 17: $305-317$.

Markolf KL, Shapiro MS, Mandelbaum BR, Teurlings L (1990) Wrist loading patterns during pommel horse exercises. Journal of Biomechanics, 23: 1001-1011.

Normile D (1996) Where is women's gymnastics going? International Gymnast, 38: 46 $-47$.

Palmer AK, Glisson RR, Werner FW (1982) Ulnar variance determination. Journal of Hand Surgery, 7: $376-379$.

Rowland TW (1993) Risks of sports participation in children: the Pretoria experience. Pediatric Exercise Science, 5: 299 - 300.

Ryan J (1995) Little girls in pretty boxes: the making and breaking of elite gymnasts and figure skaters. New York: Doubleday.

Steyers CM, Blair WF (1989) Measuring ulnar variance: a comparison of techniques. The Journal of Hand Surgery, I4A: 607-612.

Vandenbussche S (2002) Ulnar variance as related to basic motor abilities in female gymnasts: a longitudinal study. (Unpublished master thesis - in Dutch) / Prom. Prof. A.L. Claessens) Leuven: Faculty of Physical Education and Physiotherapy, Katholieke Universiteit Leuven. 
Série

Investigação

Imprensa da Universidade de Coimbra

Coimbra University Press

2010

- U r

C • 